\section{บ耐火物の研究における 放射性同位元素の応用}

\section{池ノ上 典・開田 丈夫 （黒崎窯業株式会社技術部）}

\section{I. まえがき}

近年, 放射性同位元素 (Radio-isotope) が新しい研 究手段として各方面に応用され，着々と研究成果をあ げつ」あるが，篤業方面とはこれを用いた実験例が割 合飞少い。箻者らは $\mathrm{Fe}^{59}$ を入手し，これをトレーサ 一として，耐火物の加熱による層移動汇関する簡単な 実験を行つたが，その概要を報告すると共に，一般的 な放射性同位元素の応用例を以下飞説明する。すちろ ん, “筆者らはその道の専門家でないので, 詳しいとと は専門書に譲り,こっには極めて概観的な説明に止め る。

\section{1. 放射性同位元素の概念}

質量は異るが，化学的性質の等しい原子核を同位元 素とよび，そのうちで放射性を有するすのを放射性同 位元素という。例えば， Ferは $\mathrm{Fe}^{54}$ から Fe $\mathrm{Fe}^{59}$ まで の6 種類の同位元素があり,その中で放射性を有する すのは $\mathrm{Fe}^{55}$ と $\mathrm{Fe}^{59}$ である。放射性元素はそれぞれ 固有の半減期を有し, 半減期ごとと放射性の強さは $1 / 2$ となる。この半減期は, 短いすのは秒の単位から, 長 いものは何万年以上のすのまである。人工放射性元素 は, このよ 5 K $\beta$ 線, $\gamma$ 線を出して崩壊し, 強度が減 じてゆくのであるが，その工業方面への応用は，

(1) 放射線源として，および

（2）放射性を追跡する標䜾，すなわちトレーサー (Tracer) として

の二つの方法で利用されている。例えば写真乳凧を感 光せしめる作用を利用して，X線と同様写真が撮れ るが，この方法をオートラジオグラフィーと呼ぶ。又 放射性同位元素の存在する位置と量を定性的又心定量 的に知る為用 5 る例えば $\mathrm{Fe}^{59}$ は普通の $\mathrm{Fe}$ 等と 化学的には全く同一の行動をとり，その放射性を追跡 するととによつて Fe の行動を容易に知り得る。

これらの放射性の測定垶置は非常飞発達普及しつ」 あるため，今後ますます各方面と利用されるようとな るであろらが, ただ,こ」と注意しなければならない ことは, 健康管理の問題である。この放射線をある限 度, 例觉ば手の場合は 1 週 1 レントゲンの露出が許 容, 又身体の任意の部分では総照射線量 1 週 300 ミv レントゲンをこ党る場合は，骨の芽胞を侵されたり，
止血病になつたり，その他の身体障害を生ずる危険性 があるために，詳細の取扱い注意が規定されている。 こよにはその詳細は略すが，このような取扱い上の危 険を括かしてまでも，これらの使用はますます広範囲 飞発展して行く㓰勢にある。

\section{1. 工業方面への応用例}

（a）透過試験： Co60 を用い 500 mc. で距離 15 〜60 in., 露出時間 $5 \sim 60 \mathrm{hrs}$. K $1 / 4^{\prime \prime} \sim 6^{\prime \prime}$ の厚みの 鋳鉄の透過写真ができる。

（b）㖟収を利用した厚さ測定器：連続的飞生産さ れる薄鋼板や，ゴムべルトの厚みを測定するのに，下 側仿放射元素を置き，上とガイガー管を置き，厚みを 連続的に測定して，変化があると自動的てローラーの 間隔を調節する。

（c）探鉱法に利用：Oil Shale, 層, Sand stone 層, Lime stone 層等か，放射線の散乱の大中小を利 用して探鉱する。

（d）ベルト，織機等の帯電による妨害を防ぐのに $\mathrm{Co}^{60}, \mathrm{Sr}^{89}$ 等の $\beta, \gamma$ を利用。

(e) 揅擦の研究 : ピストンやシリンダー間の摩擦 による減耗の研究に，一方の面に放射性を与えて置き 使用後相手の面の放射性を，討数管又はフィルムによ り調べる。

（f）気体液体の流れの測定：石油工業で, 精油所 そ送るのに長い送油管飞質の違5原油を入れ，質の変 り目沃 $\mathrm{Ba}^{140}$ を入れて送ると区別することができる。

（g）人絹ビスコース法で製系する時， $\mathrm{CS}_{2}^{\prime}$ からの

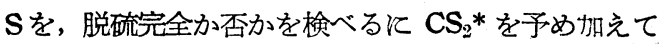
置く。

\section{IV. 臨床医学方面への応用}

A. 治療

a. 撰択的摄取の利用 : 甲状腺が Јを撰択的に摄 取するので，甲状腺疾患の手術治療使用す。

b. 圈換反応の利用：骨飞撰択的飞吸収された Ca と Sr が置換する点を利用して，Sr $\mathrm{Sr}^{122}$ を骨疾患と用 いる。

c. 腫癔の近距離照射 : 消化器, 子宮等の癌の治 療に $\mathrm{Co}^{60}$ を使用する。 Ra の代用になる。

B. 診 断

（a）腫嫖の診断： $\mathrm{P}^{32}$ は発育の盛んな腫痗細胞飞 集るので，これをガイガー管で調べて，診断手術てそ の範囲の決定飞利用す。

（b）循珢時間の測定： $\mathrm{Na}^{24}$ を食塩水の形にして 静脈注射をして，ガイガー管により゙その循環を皮膚の 上から測定, 全身文は局所性循環障害の診断応用さ れる。 


\section{V. 生化学への底用}

(a) $\mathrm{CO}_{2}$ 固定反応：動物户緑色植物等山, $\mathrm{CO}_{2}$ を同化することがあきらかであるが，微生物の一種ブ ロピオン酸ベクテリヤはグリセリン培養すると,プロ ピオン酸のほかに琥珀酸を相当量生ずる。すなわち， $3 \mathrm{C}$ 化合物から $4 \mathrm{C}$ 化合物を生ずる。これは空中の $\mathrm{CO}_{2}$ を固定するによると推定した。この実証のために C11 やC $\mathbf{C}^{14}$ が用いられた。この種の反応の一例は

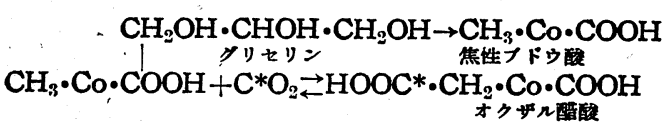

（b）微生物によるビタミン $\mathrm{B}_{12}$ 合成：反贸動物の 胃の中には，人閒の抗悪性賀血因子であ.る $\mathrm{B}_{12}$ と同質 のCo 錯塩のあることがわかつたので， $\mathrm{B}_{12}$ を生産す るための研究に, $\mathrm{Co}^{60}$ を含む培養基中に菌を培養し て研究した結果, 培養基中の Co を吸収し， $\mathrm{B}_{12}$ を合 成することがわかつた。

（c） 赤血球の寿命：へモグロビンの主成分へミン は,グリシンというアミノ酸により体内で合成される が，放射性を与えたラベルグリシンを普通のグリシン 飞混合し，新しいーミンを合成するとラベルヘミンが 現れてくる。ラベルグリシンの拄取を止めてから， ラ ベルヘミンは濃度を低下せず, 100 日す過ぎてからや つと低下を始めたので, へミンは相当安定な物らしく 赤血球は従つて絶えず分解して作られる物ではなく， 一定の寿命があることがわかつた。人血では約 130 日 の寿命がある。

\section{V1. 化学への応用}

\section{A. 分析化学}

(a) 分離：アルカリ元素, アルカリ土金属等のよ 3 K, 類縁元素相互の分離確認の難しい物飞, 放射性 同位元素の応用は極めて有効である。 $\mathrm{Na}, \mathrm{K}, \mathrm{Rb}, \mathrm{Cs}$ の分離次つき,イオン交換樹脂アンバーライト $1 \mathrm{R}-100$ を利用 $\mathrm{Na}^{24}, \mathrm{~K}^{42}, \mathrm{Rb}^{86}, \mathrm{Cs}^{134}$ を用いて研究された。 まず，イオン交換樹脂に $\mathrm{Na}^{24}$ 以下の放射元素を吸 収させて置き，始め 0.1-NHCI で洗い, 流出量が○ 印の所まで行う。次に N-HClで処理する。一方, 流

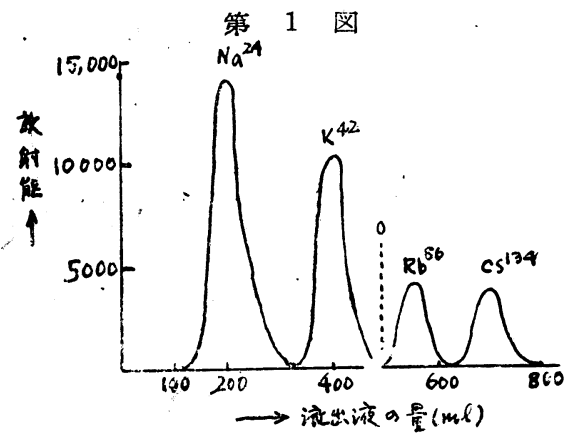

出液は連続的に計数管で測定すると第 1 図のような開 係となり，完全分離可能なととがわかる。

(b) 徽元素の追跡：放射性原子から出る放射線 は，極めて谷易に高率で検出されるから，追跡しよ5， とする元素に放射性同位元素を加空ておけば, 化学的 行動を極微量まで知ることができる。

(c) 微量吸盖国の測定： $\mathrm{Pb}$ の㙁類に, これの放 射性同位素である $\mathrm{ThB}$ を用いた。 $\mathrm{Pb}$ の洗湺効果の 研究結果 $10^{-6} \sim 10^{-5} \mathrm{~g}$ Pb の吸着が炉紙泟あるととま でわかつた。

\section{B. 一般化学における応用}

(a). 交換現象の解明： 化学反応が終結して平衡 状態になつた時, 溶液中のイオンや沈澱を形成する同 種イオンは，互に交換し合うすのであるが，これに同 種の放射性元素を使用すると, 非常簡単々その現象 を認識できる。そのほかに $\mathrm{Cl}^{-}$と $\mathrm{Cl}_{2}, \mathrm{Br}^{-}$と $\mathrm{Br}_{2}$, $\mathrm{J}-$ と $\mathrm{J}_{2}$ 等は常温で交換する。 $\mathrm{S}^{\prime \prime}$ と $\mathrm{SO}_{4}{ }^{\prime \prime}, \mathrm{SO}_{3}{ }^{\prime \prime}$ と $\mathrm{SO}_{4}$ " 等のSの交換は $100^{\circ} \mathrm{C} て ゙ す$ 行われないが, $\mathrm{S}^{\prime \prime}$

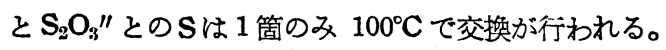

(b). 化学反応機構の解明 : $\mathrm{MnO}_{2}$ か $\mathrm{H}_{2} \mathrm{O}_{2}$ 溶液 の分解反応を行う機構の解明に $\mathrm{Mn}^{52}$ を使用した。

$$
2 \mathrm{H}_{2} \mathrm{O}_{2} \stackrel{\mathrm{MnO}_{2}}{\longrightarrow} 2 \mathrm{H}_{2} \mathrm{O}+\mathrm{O}_{2}
$$

この触媒反応途中で, $\mathrm{MnO}_{2}$ は次のよ5な変化をす゚る と考えられる。 $\mathrm{MnO}_{3} \rightarrow \mathrm{Mn}^{++} \rightarrow \mathrm{Mn}(\mathrm{OH})_{2} \rightarrow \mathrm{MnO}_{2}$ こ の証明のために, $\mathrm{Mn}^{52}$ を $\mathrm{MnO}_{2}$ 飞少量加兄て置く と，反応しなければ $\mathrm{Mn}^{52}$ のまつであるが，反応す ると $\mathrm{MnO}_{2} \rightarrow \mathrm{Mn}^{++}$になる時に $\mathrm{Mn}^{52}$ る反応飞入り, $\mathrm{MnO}_{2}$ 中の $\mathrm{Mn}^{52}$ は $\mathrm{Mn}^{++}$の中にも入り, 均一飞分 布することからこの反応が生ずることを確めた。

\section{C. 雪文化学人の応用}

$\mathrm{Zn}$ 西解液中の $\mathrm{Pb}^{++}$の行動の研究。

D. 有機化学部門て合成や反応の研究に $\mathrm{C}^{14}$ を使用す

\section{VII. 農業への応用}

（a） 植物細胞への影響：X線やラジウム等による 異常核分裂と同型の異常が生ずるので, 植物遺伝学の 基碟的研究に大きい貢献をする。

(b) 砂糖裁培による作物栄漛の研究

(c) 植物体内に $\mathrm{P}^{32}$ を吸収させて, 組織内の分布 状態を研究するのにオートラジオグラフィを行う。一 例として, トマトが微量の $\mathrm{Zn}$ を如何に利用するかの 研究飞, $\mathrm{Zn}^{65}$ を含む溶液を吸収させると組織中に入 り, 最後に果実を薄片として写真乾板上に扔き，その 結果を見ると, 未熟の時は比較的芯から種沉集るが, 熟すると外皮の方に多く集合することがわかる。 


\section{VIII. 览業への応用}

䇺業方面に括ける同位元素の応用は，ガラス工業方 面を除いては外国でああまり行われていないが，筧業


を研究するのに, 将来は有用な科学的手段になると思 われる。

J.R. Johnson は, Radioisotopes Induntrial Applications の中に, 篤業方面に推るアイントー プ使用の研究項目を次のようと示しているి。

(a) 拡散と反応の研究。

（b）揮発性の研究，例壳ばガラスベッチ中のセレ ニウムの損失量。

(c) 陶磁器の金, 白金の厚み, 又釉薬の厚みの 測定。

(d) 混合の問題。

(e) 吸着の研究。

(f) 自動比重調整'(特許)。

（g）ガスや液体の流れの研究。

(h) 自動操炉法。

（i）表面の問題の研究，例えばガラス表面の悪化

（j） X線やラジオ装置によらねばわからないよう な，かくれた浮子や物質の位置の指標。

しかしながら、トレーサーとして使用に適した性質 を持つ同位元素は, 半減期等の関係上すべての元素に あるわけではないが，トレーサー用同位元素の多数は 窵業界で使用可能なととは幸である。

次にトレーサー用アイソトープとして要求される元 素の性質は次のようである。

(i ) 検知される位の放射能を有すること。

(ii) 実用性ある位の半減期を持つこと。

(iii) 非常飞長い半減期ではいけないが, 測定に困 らぬ位のものであること。

（iv）使用に充分な量が，容易汇製造されるような アイソトープであるとと。

次に, 竿業方面の研究に使用される放射性元素の一 覽表を掲げる。

\section{第 1 表}

Some Radioisotopes of Possible Value in Ceramic Research

\begin{tabular}{|c|c|c|c|c|c|}
\hline Symt & $\begin{array}{l}\text { Mass } \\
\text { Number }\end{array}$ & $\begin{array}{l}\text { Half } \\
\text { Life }\end{array}$ & Beta & Gan & $\begin{array}{l}\text { e V) } \\
\text { nma }\end{array}$ \\
\hline $\mathrm{Sb}$ & 122 & $2.8 \mathrm{~d}$ & $1 . \overparen{36 \quad 1.94}$ & 0.57 & \\
\hline $\mathrm{Sb}$ & 124 & $60 \mathrm{~d}$ & $2.37 \quad 0.65$ & 2.04 & 0,71 \\
\hline As & 76 & $26.8 \mathrm{~h}$ & $2.49 \quad 3.04$ & 0.55 & 1.20 \\
\hline $\mathrm{Ba}$ & 131 & $11.7 \mathrm{~d}$ & $\mathrm{~K}$, & 0.22 & 0. \\
\hline $\mathrm{Bi}$ & 210 & $5.0 \mathrm{~d}$ & $1.17 \propto 4.77$ & none & \\
\hline $\mathrm{Cd}$ & 115 & $2.3 \mathrm{~d}$ & $\begin{array}{ll}1.13 & 0.6\end{array}$ & $0: 65$ & \\
\hline
\end{tabular}

\begin{tabular}{lrrcccc}
$\mathrm{Ca}$ & 45 & $152 \mathrm{~d}$ & 0.25 & \multicolumn{3}{c}{ none } \\
$\mathrm{Ce}$ & 141 & $28 \mathrm{~d}$ & 0.56 & & 0.14 & \\
$\mathrm{Cs}$ & 134 & $2.3 \mathrm{y}$ & 0.66 & 0.09 & 0.57 & 0.79 \\
$\mathrm{Cr}$ & 51 & $26.5 \mathrm{~d}$ & $\mathrm{~K}$, & $1-$ & 0.32 & \\
$\mathrm{Co}$ & 60 & $5.3 \mathrm{y}$ & 0.31 & & 1.16 & 1.30 \\
$\mathrm{Cu}$ & 64 & $12.8 \mathrm{~h}$ & 0.57 & 0.66 & 1.35 & \\
$\mathrm{Au}$ & 198 & $2.7 \mathrm{~d}$ & 0.96 & $1^{-}$ & 0.41 & \\
$\mathrm{I}$ & 131 & $8 \mathrm{~d}$ & 0.60 & 0.32 & 0.37 & 0.64 \\
$\mathrm{Ir}$ & 192 & $70 \mathrm{~d}$ & 0.59 & $1-$ & 0.20 & 0.61 \\
$\mathrm{Fe}$ & 59 & $46.3 \mathrm{~d}$ & 0.26 & 0.46 & 1.10 & 1.30 \\
$\mathrm{La}$ & 140 & $40.4 \mathrm{~h}$ & 0.90 & 1.40 & 1.63 & 0.87 \\
$\mathrm{Mo}$ & 99 & $67 \mathrm{~h}$ & 1.3 & 0.24 & 0.24 & 0.84 \\
$\mathrm{Os}$ & 193 & $32 \mathrm{~h}$ & 1.5 & & 1.2 & \\
$\mathrm{P}$ & 32 & $14.3 \mathrm{~d}$ & 1.71 & & none & \\
$\mathrm{Pt}$ & 197 & $18 \mathrm{~h}$ & 0.7 & & & \\
$\mathrm{~K}$ & 42 & $12.4 \mathrm{~h}$ & 2.07 & 3.58 & 1.51 & \\
$\mathrm{Rh}$ & 105 & $36.5 \mathrm{~h}$ & 0.66 & $1-$ & 0.33 & \\
$\mathrm{Rb}$ & 86 & $19.5 \mathrm{~d}$ & 1.82 & 0.71 & 1.08 & \\
$\mathrm{Se}$ & 75 & $125 \mathrm{~d}$ & $\mathrm{~K}$, & $1-$ & 0.45 & 0.08 \\
$\mathrm{Si}$ & 31 & $170 \mathrm{~m}$ & 1.8 & & none & \\
$\mathrm{Ag}$ & 110 & $225 \mathrm{~d}$ & 0.59 & 0.09 & 1.52 & 0.94 \\
$\mathrm{Na}$ & 24 & $14.8 \mathrm{~h}$ & 1.39 & & 1.38 & 2.76 \\
$\mathrm{Sr}$ & 89 & $55 \mathrm{~d}$ & 1.5 & & none & \\
$\mathrm{S}$ & 35 & $87.1 \mathrm{~d}$ & 0.17 & & none & \\
$\mathrm{Ti}$ & 51 & $72 \mathrm{~d}$ & 0.45 & & 1.0 & \\
$\mathrm{~W}$ & 185 & $74 \mathrm{~d}$ & 0.43 & & & \\
$\mathrm{~W}$ & 187 & $24.1 \mathrm{~h}$ & 0.62 & 1.35 & 0.77 & 0.68 \\
$\mathrm{Zn}$ & 65 & $250 \mathrm{~d}$ & $\mathrm{~K}$, & $1-$ & 1.11 & \\
$\mathrm{Zr}$ & 95 & $65 \mathrm{~d}$ & 0.39 & 1.0 & 0.73 & 0.23 \\
$\mathrm{~K}$ & & & & & &
\end{tabular}

$\mathrm{K}: \mathrm{K}$ electron Capture d: day, $\mathrm{y}$ : year $1^{-}$: internal conversion electrons $h$ : hour $\mathrm{m}$ : minute

(G.H. Guest : "Radioisotopes Industrial applications" $81 \mathrm{p} よ り)$

次㳊射性同位元素を利用した研究の例。

（i）ガラスバッチの溶触： ガラスの溶融には， ガラスバッチの細かさと均一さが溶融状態に強く影響 することと,その䦎の物理化学的变化を研究するのに, 放射性元素をトレーサーとして愹融研究をした。

Lindroth, S.A., "Some Examples of Radioactive Tracing Glass Technology," Glass Ind., 1948, 29, 320

Lindroth S.A., "Study of Glass Batch Meiting by Radioastive Tracing," $J$. An. Cdran. Soc., 1949, 32, 198

（ii） ガラス構造の研究：珪酸ガラスの成分イオ ンの昖散の割合よりガラス構造を研究した。すなわち ソーダライム硝子の中へ $650^{\circ} \mathrm{C} て ゙ \mathrm{Na}^{24}$ が拡散する状 態を測定した。

Blau, H.H., and Johnson, J. R., "Investigation of the Glass Structure Using Radioactive 
Tracers" Glass Ind., 1949, 30, 393 ; Ceram. Abs., 1949, 32 [6] 142

(iii) ガラス表面の脫アルカリ能率の研究 : $\mathrm{Na}^{24}$ を用いて，ガラス表面の脱アルカリ能率の研究をした が, ガラス試料はガラス中の $\mathrm{Na}^{23}$ をサイクロトロン の重水素で $\mathrm{Na}^{24}$ 亿変じて放射性として, 脱アルカリ 用 (粘土や $\mathrm{Cr}_{2} \mathrm{O}_{3}$ ) と共に加熱すると, $\mathrm{Na}^{24}$ のプロ トンはガラスから脱アルカリ削に移転する。冷却後, 脱アルカリ剤を除去して，この中の放射量を測定する と, その量は時閫と温度と共増加するととがわかつ た。その成分と $\mathrm{Na}^{24}$ の放射能の強さの分布から, 脱 アルカリ威の影響が決定された。

Fitzgerald, J.V., "Determination of Efficiency of Dealkalization of Glass Surfaces by Radioactive Sodium," Glass Ind., 1949, 30, 259; Ceram. Abs., 1950, 33, 178.

(iv) ThX を用い, そのエマナチオンをイオン化 槽で測定，ガラス粉末の半融怙よび融解転位点を調へ t。

Nils Åberg Arkiv, Kemi. Mineral. Geol., 1944, 18 A. 9 pp ; Ceran. Abs., 1949, 3280

(v) ガラスの砫究にエマナチオン法の応用 Glass Industry, 1949, 30, 31 33; Cram. Abs., 1950,

33, 120

（vi） アルカリ漫蝕に関連してガラス面への放射性 燐酸イオンの吸着： ガラス面のアルカリ浸蝕を示す のと放射性燐を燐酸ソーダとしてその吸着量を代つて 示す。軟質ガラスを数分間 $80^{\circ} \mathrm{C} て ゙ ~ \mathrm{NaOH}$ 溶夜処理 すると常温の燐酸イオン吸着が数倍する。パイレック スでは更に前処理を長くしないそ同様な結果にならな い。このアルカリ処理の時 $\mathrm{Zn}$ イオンがあると燐酸イ オンの吸着は増加するし, 多価陽イオンの吸着によつ て橉酸の吸着が容易になる。

J.W. Hensley, J., Am. Ceram. Soc., 1951, 34, [6] 188 92

（vii）ガラス浸蝕を受けた槽璌耐火物を放射性 と した物の Na の分布： 溶融板ガラス中に耐火物試料 2 種（シャモット質扣よび溶融鋳造耐火物）を入れ， ガラスから浸透した Na の濃度と所在を, 2 種の原子 物理的方法によつて示された。すなわち, 試料に放射 性を与える方法と放射性同位元素の追跡法により, 結 果はオートラジオグラフィーにより示された。

a) Activation 法（試料その物を放射性飞する法） 小形槽篣を使用し，その中に 2 種の試験煉瓦を入れ $1450^{\circ} \mathrm{C}, 77$ 時間熔融板ガラスの流れ浸漬した後, カ ッターで浸蝕面に直角に切断し, サイクロトロンから 出る加連重水素原子核を当てたら, 耐火物の 0.002 in の厚みでストップされ，Na は原子核変化し放射性に
なり，所在と濃度が測定された。

b) Tracer 法 白金坩堝中に, 粉碎板ガラス粉と 半減期 15 時聞の $\mathrm{Na}^{24}$ を $\mathrm{Na}_{2}{ }^{*} \mathrm{CO}_{3}$ として, $\mathrm{HCl}$ で 中和したるのを加えて溶融して, $1450^{\circ} \mathrm{C} て ゙ 2$ 種の耐 火物の棒を 19 時閒浸漬したるのをカッターで切り， オートラジオグラフィーにより結果を求めた。

K.M. Laing, D.E. Emhiser, J.V. Fitzgerald, R.E. Jones "The Location of Sodimm by Nuclear Activation in Glass-Corroded Tank Block Refractories," J. Amer. Cerm. Soc.

（viii）珐瑯における Co の研究：放射性CoO の 少量を含むフリットと含ま妨フッットとを作り，各別 に下がけ釉薬を作つた。これを $4 \times 4$ in の鉄板に矣り $790^{\circ} \mathrm{C}, 2$.分乃至 $960^{\circ} \mathrm{C} 10$ 分の範再で条件を変へて 焼成し, 融着試験を行つたら, 放射性 Co の入つた方 がややよかつた。次に $2 \times 2$ in の鉄板に染り, $790^{\circ} \mathrm{C}$ 4 分, $855^{\circ} \mathrm{C} 4$ 分, $960^{\circ} \mathrm{C} 6$ 分の焼成を行い, 愹融 $\mathrm{NaOH}$ で㧼瑯のみ除去し鉄板の放射性測定をする。 次に, 10\% クエン酸アンモンで $\mathrm{Co}$ と $\mathrm{Fe}$ の酸化物 を除去し，鉄板の放射性を測定したら，始め $1182 \mathrm{c} / \mathrm{m}$ が $207 \mathrm{c} / \mathrm{min}$ に下つた。これは, いずれの薬品にも 作用されない層が，泆瑯と金属鉄の中間とあつて，そ の層の鉄の中に Co* が拡散していることを示めす。

"A Radioisotope Study of Cobalt in Porcelain Enamel," J. Am. Ceram. Soc., 1952 35, [5].

(ix) セレニウムの揮発 : ガラス配合に Se ${ }^{175}$ の 少量を（1\%以下）加へ充分混合し，溶融温度仅加熱 冷却し，試料はガイガー計数管で測定する。

J.R. Johnson "Radioactive Tracer Methods Applicable to Ceramic Research "Ceramic Bulletine, January 1950

\section{IX. 放射性同位元素による層移動の研究}

フォルステライト耐火物は，その一端より加熱され る場合には，その成分である $\mathrm{Ca}, \mathrm{Fe}, \mathrm{Al}$ 等は熱㹡 散して移動し，始めの組成と異つた層を生成するため この異状構造が，スポーリングの一つの原因となる。

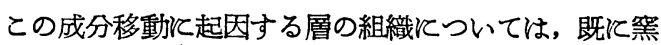
業協会誌济報告したが，その検討の一方法としてUを トレーサーとして Ca の移動を追跡したが，期待に反 してUと Caは各別の層に移動して失敗に終つた。そ こで $\mathrm{Ca}, \mathrm{Fe}$ の移動を知るにはどうしてもそれぞれ $\mathrm{Ca}, \mathrm{Fe}$ の放射性同位元素でなければいけないととが わかつた。それで $\mathrm{Fe}^{59}, \mathrm{Ca}^{45}$ を輸入するようと申請 したが，今年 3 月に $\mathrm{Fe}^{59} / \mathrm{m} . c$. が入荷した。これは 半滅期 46.3 日で $\beta, \gamma$ 放射で, 不純物として $\mathrm{Co}^{60}$ を少量含有しているので, 東大理学部齊藤助教授の御 指導下に $6 \mathrm{~N}-\mathrm{HCl}$ 飽和エーテルで $\mathrm{FeCl}_{3}$ を抽出して 
完全に $\mathrm{Co}^{60}$ を分離した。

〔試料の製作〕

原料は鉄乳鉢で碎き， $1 \mathrm{~mm}$ 䇻をパスして充分混合 したものを深い容器に入れ, 苦汁と $\mathrm{Fecl}_{3}$ 溶液 $2 \mathrm{cc}$ を加劣，ゴム手袋を着用して手で充分て混合した。配 合は第 2 表の通り。こつと莣汁は比重 1.26 で, 外が けに $8 \%$ 加えた。

\section{第 2 表}

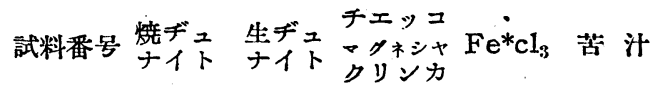

\begin{tabular}{|c|c|c|c|c|c|}
\hline FD 100 & 100 & & & 2 c.c. & $8 \%$ \\
\hline FD 70 & 70 & & 30 & " & $"$ \\
\hline GD 70 & & 70 & 30 & " & " \\
\hline GD 100 & & 100 & & " & " \\
\hline 無 印 & & & 100 & " & " \\
\hline
\end{tabular}

$\mathrm{Fe}^{*} \mathrm{Cl}_{3}$ は配合 $1 \mathrm{~g}$ 当り $0.1 / \mu$.c. の強さとなる。 但し, GD 70 と GD 100 は $\mathrm{Fe}^{*} \mathrm{Cl}_{3}$ 溶液が不足した

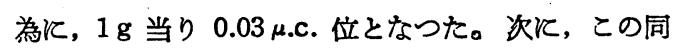
一配合で同時に $115 \times 29 \times 33(\mathrm{~mm})$ の大きさの試料を 2 ケずつ製作し, 乾燥後エレマ炉で SK 20 亿燒成し， 1 ケ $(A)$ を比較のためと残し，他方 $(B)$ をエレマ炉壁 飞積み, 片面を $1400^{\circ} \mathrm{C}$ 飞 3 時間保ち, 反対側を空冷 した。試料加熱温度は炉内温度と空冷面温度を測定し た。

第2図エレマ淤中で試料加熱の図
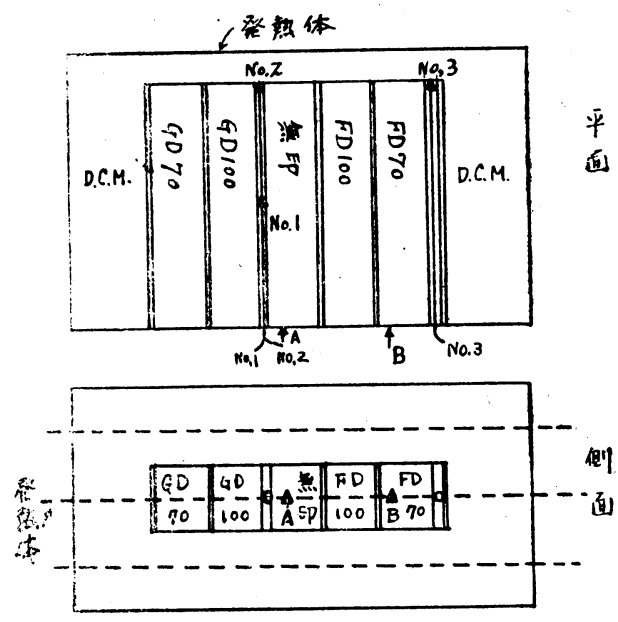

No.1,2, 3: 白金一ロジウム カップル A, B：表面温度訪测定位圈

冷却後, 取出した試料 $(A)$ は大体 5 種の色層に分れ るのでそそれぞれ対応する試料 $(B)$ と比較して，Aの 色層㴟対応する $B$ の層を目切で切断し，これを各個別 飞粉砕し, 四分法で 2 3 $\mathrm{g}$ 飞縮分したすのを瑪璃乳
第 3 表

加熱师内温度と表面温度との関保

\begin{tabular}{|c|c|c|c|c|}
\hline \multirow{3}{*}{$\begin{array}{l}\text { No. } 1 \\
495^{\circ} \mathrm{C}\end{array}$} & \multicolumn{2}{|c|}{ 炉内温度 } & \multicolumn{2}{|c|}{ 表面温度 } \\
\hline & No. 2 & No. 3 & A & B \\
\hline & $925^{\circ} \mathrm{C}$ & $925^{\circ} \mathrm{C}$ & $225^{\circ} \mathrm{C}$ & $185^{\circ} \mathrm{C}$ \\
\hline $560 "$ & $1110 "$ & $1100 "$ & $255 "$ & $210 "$ \\
\hline $610 "$ & $1400 "$ & $1400 "$ & $275 \prime$ & $230 "$ \\
\hline $685 "$ & $1400 "$ & $1400 "$ & $320 "$ & $260 "$ \\
\hline $740 "$ & $1420 "$ & $1420 "$ & $345 "$ & $280 \prime \prime$ \\
\hline $770 "$ & $1400 "$ & $1400 "$ & $350 "$ & $275 "$ \\
\hline $770 "$ & $1420 "$ & 1415 " & $350 "$ & $280 " \prime$ \\
\hline
\end{tabular}

錸で正確に 10 分間ずつすり, 微粉として穊とかけず ガラスシャーレに入れ, エヤバスで充分乾燥後デシヶ ーター中に放冷す。これを試料とする。

\section{〔準備と測定]}

試料は銅製シャーレ（直径 $5 \mathrm{~cm}$, 高さ $2 \mathrm{~cm}$, 厚み 1 2 mm) 亿化学天种で正確次 $1 \mathrm{~g}$ 科取し, アルコー ル 2〜3c.c. を加えて平にしてェヤバスで乾燥し，テ シケータ中に放冷後カウンターで $\beta, \gamma$ を測定した。 測定は九大理学部野中教授の御指導によつた。

まずBack ground 汒 20 分間測定して 1 分間の平 均カウントを求めた。ガイガー管と試料面との距離は 50 m.m.。試料のカウントは 5 分間ずつ 3 回行い, 同 時に時間を記録して 3 回の平均值を求めて, その值よ り Back ground を差引きデーター(I) とする。しか し, $\mathrm{Fe}$ *の崩罝により時間の経過と共にカウント数も 变化するので, 時間経過によるカウントの補正を行つ た。とれを $\left(I_{0}\right)$ とす。



上の $I_{0}$ のデータをグラフに示す。 
第3図 $I_{0}$ の 值

（測定值より Background を引き

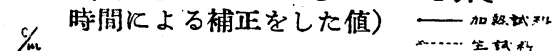

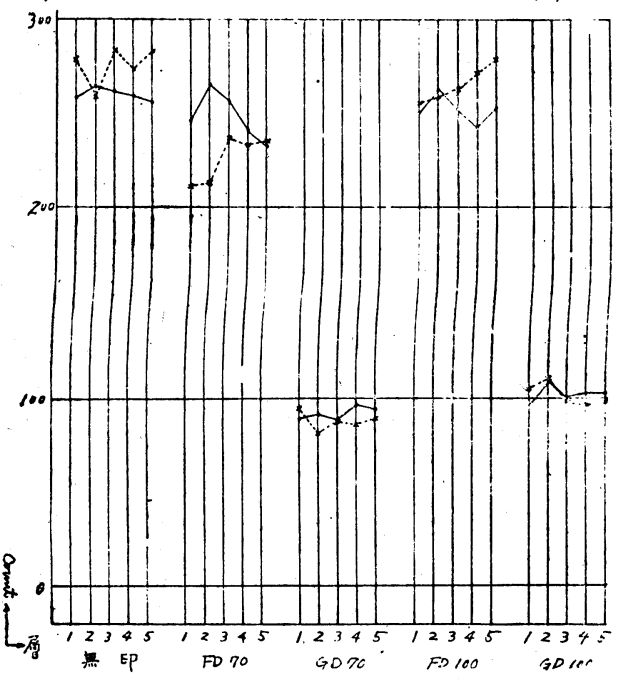

次に, 加熱物 $B$ と $A$ との差の $A$ 飞対する比 $[(B-$ $A) \times 100 】 / A$ を求め, これを移動動率と呼ぶ。 第 5 表 移動率 $\%\left(\frac{B-A}{A} \times 100\right)$ 移動率 $\%\left(\frac{B-A}{A} \times 100\right)$

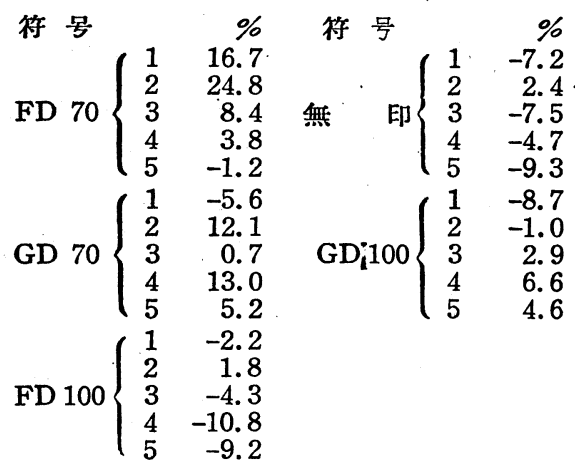

次に移動率のグラフを示す。

第 4 図 移動率 $B-A / A$

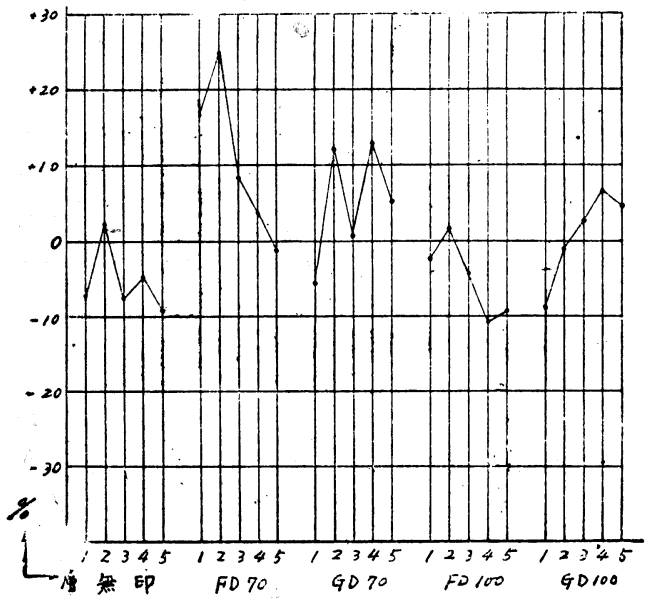

この移動率から見ると, 大体 2 層内至 4 層の辺りに 集合しているが, GD 70 と GD 100 とは $A$ と $B$ のカ ウントは非常に接近していて，互いに誤差範囲に入る ため, 果して実験誤差か移動が少なかつたためかわか らない。

註：測定誤差は $\pm V \overline{\text { i }} \mathrm{c} / \mathrm{m}$ である。

$$
\text { （結果） }
$$

以上の実験では， $\mathrm{Fe}^{59}$ の移動量の少いための測定

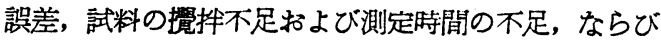
にアイソトープ取扱い不馿れのため等から，充分完全 な実験はできなかつたが，あきらかに加熱により移動 して, 既報の分析結果とも大体一致する傾向を得たの で,一つの実験例として報告する。

\section{（結論）}

以上のよ5に，放射性同位元素は各種の分野の研究 に盛んに使用されつ〉あるし，又，既に医学方面では 治療に, 工業方面で測定や品質工程管理面の一助とし て, 実用に供せられつ」あるが, 将来は更にるつと広 い分野にわたつて使用されるよ5になるであるう。し かし，今日わが国では，まだサイクロトロンす未完成 の現状であり，ほとんどアイントープの大量生産は不 能であり, 全部米, 英, カナダ等に依存の状況である から,希望の元素が希望の時期飞予定通り入荷しない。 従つて, 半減期の短い元素等は使用不能で, おのずか ら研究にも一定の制限が生じている。又, 輸入される 関係上, 運㶵や容器返送費等费用が嵩むので, 早くわ が国でも原子炉ができて，ラジオアイソトープが安価 飞大量生産せられ，これが日本の平和産業の発達や， 学術研究に大いに使用されることを希望する。

\section{参考文 献}

1. G.H. Guest, "Radioisotopes Industrial Applications"

2. K.M. Laing, D.E. Emhiser, J.V. FitzgeraId, R.E. Jones "The Location of Sodium by Nuclear Activation in Glass Corroded Tank Block Refractories", Jour. Amer. Ceram. Soc., 1951, 34, [12]

3. William N. Harrison, Joseph C. Richmond and Joseph W. Pitts "A Radioisotope Study of Cobalt in Porcelain Enamel" ibid., 1952 35, [5]

4. J.R. Johnson "Radioactive Tracer methods Applicable to Ceramic Research", Ceramic Bulletine 1950 No. 1

5. 日本放射性同位元素協会 第 2 回放射性同位元 
素講習会講義集

京大工学部 四井手氏 放射性同位元素の工業 的応用

京大理学部 石 橋 氏 放射化学実験法分析及 び一般化学への応用

岐 皋 大三宅氏放射性同位元素の䠛林 医学への応用

京大田中氏 放射性同位元素の生化 学への応用

\section{第 16 回セメント研究部会例会}

本会では去る10月 21 日, 東京駒込の建設省土木研究 所会議室で第 16 回例会を開き，中条世話人の司会て 下記の研觉発表が行われ，活発な討議の応酬があつ た。

\section{1）比熱についての雑話}

科学研笔所 笠井 (康) 部員

緱暁飞関保深い諸種ガス $\left(\mathrm{O}_{2}, \mathrm{~N}_{2}, \mathrm{CO}_{2}\right.$ その他) の 比熱の数傎は, 古いすのと昨今のすのとでは相当に異 つている。1933〜35 年頃の, アメリカの研觉検討 を加えて糧めあげた Justi の表 $\left(C_{p}, \bar{C}_{p}, p=0,0 \sim\right.$ $3000^{\circ} \mathrm{C}, \mathrm{V} \cdot \mathrm{D} \cdot \mathrm{I} \cdot$ Forschung $1935, \mathrm{Bd} .6, \mathrm{Nr} .5, \mathrm{~S}$. 209/216) は, 最近の Hütte 飞す採用され, 又燃焼に 関保ある書物汇る広く載せられているようである。

比熱（真招よび平均）の実験式として Kelley (U. S. Bureau of Mines, Bull. 371, 1934) の.式, Schwarz (Archiv f.d. Eisenhüttenwesen 1936, 389/96) の式, $\mathrm{n}$ 次式, 扔の打のの主として便利上の特徽を述 ベる。

な括,ポルトランドセメント焼塊の比熱, 宸酸石灰 の分解熱飞ついても述へて見たい。

\section{2）毛細管透水測定装置}

\section{鉄道技術研究所 常山部員}

大きさ $92 \times 40 \mathrm{~mm}$ の供試体㹸対し, 水頭 $5 \mathrm{~mm}$ の圧力を有する水を, 水平のガラス管（内径3.0 3.5 $\mathrm{mm}$, 長さ 2 5 m) 飞貯兄, 供試体飞水が透ると従 い, 吸收管内の水目盛が移動し, 移動距離と時間とを 測定して透水量を求める，毛細管透水測定についての べた。話の内容は炊の諸項にわかれる。

1. 従来の文献にあらわれた二三の毛細管透水測定 装圆の批判。

2. 講演者による装圈の原理, 実際の装置, その説 明と使用法。

3. 装置の特徵をなす吸水管の二三の性質。

（1）水目盛の平衡の安定性。

（2）吸收管内の水目盛の位置による水頭の差異。

（3）測定中飞扣ける温度变化が水目盛の位置に打 よに゙す影響。
6. 加藤正夫・武谷清昭氏 放射性同位元素の工業 への応用, “生産研究 1952, 14 [3]

7. 同上

医療用放射性合金の製 造, 生産研究 1951, 3, [12〕

8. トレイサー 自然 $1949,[7]$

9.

10.

11. 抄録 窑協 $1950,[3,4,5]$ “抄録 空協 1951, [7] $1952,[5,9]$

（4）吸收管を水目盛が移動する際の残留水。

4. その他

(1) 吸收管内飞括け蒸発。

（2）装䀧全体の科量中飞括こる吸水。

（3）接触吸水 $A_{1}$ を測定する時と回数。

(4) 天种の感度飞ついて。

3）酸性河川の骨材と水質（堰堤計画に関連して） 建設省土木研究所 有泉部員

雄物川の支流玉川は，“玉川毒水“ととてて昔から種 々研究調查されて来ている。玉川は現在田沢湖潽入 され，発䉓使用されている。玉川建設を予定され る堰堤の利水効果, 水質々堤堤構造材料との関保, 未。 よび殹堤工事に予定される玉川骨材の性質について調， 查した結果を報告する。

玉川は本邦有数の酸性河川で, しかも塩酸酸性であ り 玉川温泉より約 $0.1 \mathrm{~N}$ の塩酸が $0.14 \mathrm{~m}^{3} / \mathrm{sec}$ の 割合で涌出すること飞原因する。玉川流下中の減酸狀 況々, 流入支流の重宸酸塩との関保について, 地球化 学的考察を加光た。文堰堤貯水池の終極 $\mathrm{pHy} 3.6 \sim 3.8$ であるととを推定し，これらの水と接するコンクリー ト，金属材料の性質，農業用水としての性質とついて 検討した。

玉川が導入された後の，田沢湖の水睤が変化した狀 況を調查し，田沢湖中での玉川の流動狀況，混合狀 況を等 $\mathrm{pH}$ 線, 等温線より考察し, 田沢湖の持つた緩 衝能飞言及し, 今後の田沢湖の酸性化の程度を推定し た。田沢湖が玉川下流の酸性化防止飞果した狀況につ いて述べる。

玉川骨材が，酸性水飞接するためと受けた変質狀況 を，物理的化学的性質飞ついて検討し，比重の小さい こと, 吸水率の大きいこと, 耐久性の劣ること, 灼減 が大きいこと，酸アルカリに可溶成分の多いことをあ きらかにし，示差熱分析結果についても言及する。岩 石別に分類した砂利について, 表面層と内部の化学租 成の異同を試験し, 表面層は $\mathrm{SiO}_{2}$ が多く $\mathrm{Al}_{2} \mathrm{O}_{3}$ か 特飞少く, $\mathrm{SiO}_{2}$ 性特飞可溶性であることをあきらか 飞した。この骨材はコンクリート骨材として使用した 均合コンクリート強度を低下させることをあきらかと した。 